\title{
Labour market forecasts by education and occupation up to 2024
}

Citation for published version (APA):

Bakens, J., Fouarge, D., \& Goedhart, R. (2020). Labour market forecasts by education and occupation up to 2024. ROA. ROA Technical Reports No. 002 https://doi.org/10.26481/umarot.2020002

Document status and date:

Published: 06/05/2020

DOI:

10.26481/umarot.2020002

Document Version:

Publisher's PDF, also known as Version of record

\section{Please check the document version of this publication:}

- A submitted manuscript is the version of the article upon submission and before peer-review. There can be important differences between the submitted version and the official published version of record.

People interested in the research are advised to contact the author for the final version of the publication, or visit the DOI to the publisher's website.

- The final author version and the galley proof are versions of the publication after peer review.

- The final published version features the final layout of the paper including the volume, issue and page numbers.

Link to publication

\footnotetext{
General rights rights.

- You may freely distribute the URL identifying the publication in the public portal. please follow below link for the End User Agreement:

www.umlib.nl/taverne-license

Take down policy

If you believe that this document breaches copyright please contact us at:

repository@maastrichtuniversity.nl

providing details and we will investigate your claim.
}

Copyright and moral rights for the publications made accessible in the public portal are retained by the authors and/or other copyright owners and it is a condition of accessing publications that users recognise and abide by the legal requirements associated with these

- Users may download and print one copy of any publication from the public portal for the purpose of private study or research.

- You may not further distribute the material or use it for any profit-making activity or commercial gain

If the publication is distributed under the terms of Article $25 \mathrm{fa}$ of the Dutch Copyright Act, indicated by the "Taverne" license above, 


\section{Maastricht University $\&$ ROA}

\section{Labour market forecasts by education and occupation up to 2024}

Jessie Bakens

Didier Fouarge

Rogier Goedhart

\section{ROA Technical Report}

ROA-TR-2020/2

Researchcentrum voor Onderwijs en Arbeidsmarkt | ROA Research Centre for Education and the Labour Market / ROA 


\title{
Labour market forecasts by education and occupation up to 2024
}

\author{
Jessie Bakens \\ Didier Fouarge \\ Rogier Goedhart
}

ROA-TR-2020/2

May 2020

This research has been conducted within the framework of the Education and Labour MarketProject(POA).The projectisfunded by Nationaal Regieorgaan Onderwijsonderzoek (NRO; file number 405-17-900), the UWV Werkbedrijf, the Cooperation Organisation for Vocational Education, Training and the Labour Market (SBB), and employment agency Randstad Netherlands. Four Dutch ministries contribute to the NRO funding: the Ministry of Education, Culture and Science (OCW), the Ministry of Interior and Kingdom Relations (BZK), the Ministry of Social Affairs and Employment (SZW), and the Ministry of Agriculture, Nature and Food Quality (LNV).

Research Centre for Education and the Labour Market

Maastricht University

P.O. Box 616, 6200 MD Maastricht, The Netherlands

$\mathrm{T}+31433883647 \mathrm{~F}+31433884914$

secretary-roa-sbe@maastrichtuniversity.nl

www.roa.nl

ISSN: $2666-884 X$ 


\section{Contents}

1 ROA labour market forecasts $\quad 1$

2 The forecasting model 3

2.1 Model design 3

Demand for labour $\quad 5$

Expansion and substitution demand $\quad 5$

Replacement demand and job openings $\quad 6$

$\begin{array}{ll}\text { Supply of labour } & 7\end{array}$

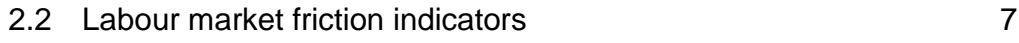

$\begin{array}{ll}\text { Friction indicator for new inflow into the labour market } & 7\end{array}$

Friction indicator for employers $\quad 8$

Labour market friction by occupation 9

2.3 New educational classification (ONR2019) 10

3 Forecasts by education and occupation 11

3.1 Future labour market prospects by education 11

3.2 Future labour market prospects by occupation 13

3.3 General expected labour market developments 14

4 Relevance of labour market information $\quad 17$

4.1 Use of labour market information by stakeholders 17

$\begin{array}{ll}4.2 \text { Labour market transparency and field-of-study choice } & 18\end{array}$ 


\section{ROA labour market forecasts}

As part of the Education and Labour Market Project (POA) ${ }^{1}$, the Research Centre for Education and the Labour Market (ROA) develops a number of research activities aimed at a better understanding of the medium-term developments in supply and demand on the Dutch labour market. These activities include analyses of the match between skills supply and demand, the development of labour market indicators for the current equilibrium between supply and demand, and labour market forecasts of supply and demand by industry, occupation, education, and region. The indicators for the current state of the labour market as well as the medium-term forecasts are gathered in an online database: the Labour Market Information System (AIS). ${ }^{2}$ This database is updated on a yearly basis. The POA project was initiated by ROA in 1986 to increase the transparency of the labour market for youngsters in order for them to make better informed decisions on their education.

The most recent forecasts, with an outlook until 2024, were published in December 2019. ${ }^{3}$ Although mid-term forecasts are less sensitive to short term variations in the economy, it is possible that the 2020 covid-19 crisis affects our findings. This report describes the main features of the POA forecasting model (Chapter 2), and briefly discusses the findings from the most recent forecast for the Dutch labour market until 2024 by occupational groups and types of education (Chapter 3 ). Finally, the relevance of labour market information and labour market forecasts for stakeholders in the labour market is discussed (Chapter 4).

1. https://roa.nl/research/research-projects/project-onderwijs-arbeidsmarkt-poa

2. See http://roastatistics.maastrichtuniversity.nl/

3. ROA (2019). De arbeidsmarkt naar opleiding en beroep tot 2024, Maastricht: ROA-R2019/7. 


\section{The forecasting model}

\subsection{Model design}

For its medium-term (six-years ahead) labour market forecasts, ROA uses a flowbased approach of labour force flows to and from the labour market. The most recent forecasts with an outlook until 2024 are based on labour market developments by economic sector, occupational group, and type of education between 1996 and 2018. The forecasting model itself is based on (explanatory) econometric models developed by ROA. The most important data inputs of the model include: 1) economic growth outlooks by the Netherlands Bureau for Economic Policy Analysis (CPB), 2) employment forecasts by industry sectors (by SEOR), 3) baseline forecasts from the Ministry of Education, Culture and Science (OCW) for the inflow of students in the labour market, 4) time series data from the Labour Force Survey (LFS) provided by Statistics Netherlands (CBS), and 5) data from ROA's School Leaver Information System (SIS).

The key advantage of this approach is that the most important processes that determine the development of supply and demand in the labour market are assessed. The ROA forecasts allow for the dynamic interplay between submarkets because the labour market is considered in its entirety. ${ }^{4}$ As the method includes substitution between different labour market segments, it is arguably superior to a partial equilibrium analysis that solely examines labour market developments from a purely sectoral perspective. ${ }^{5}$

Forecasts are generated for a total of 113 occupational groups and 108 types of education, and span the entire labour market. The forecasts are also computed for 35 labour market regions of the Netherlands, be it on a higher level of aggregation due to data constraints. The forecasts in this report, as well as the other labour market data, are usually reported for an aggregate of 13 occupational classes and 33 education categories. The fully detailed forecasts are available online: http://roastatistics.maastrichtuniversity.nl/. In line with the ILO-definition of employment, the forecasting model counts all persons between the age of 15 and 74 at work for at least 1 hour per week. ${ }^{6}$

4. CPB (2013), Economische analyse van korte en lange termijn knelpunten op de arbeidsmarkt, Den Haag: CPB Notitie, 31 mei 2013.

5. Partial forecasts can be complementary because they can satisfy the need for information on specific markets. However, they do not take into account the dynamic interplay between submarkets.

6. Bijlsma, I. S. Dijksman, D. Fouarge, A. Künn-Nelen \& D. Poulissen (2015), Veranderingen in de omvang en samenstelling van de beroepsbevolking als gevolg van de overstap op de ILO-definitie van de beroepsbevolking, Maastricht: ROA-TR-2015/6. 
Figure 1 provides an overview of the forecasting model. ${ }^{7}$ The goal of the model is to derive indicators of friction (dashed lines) from the estimates of the future demand for labour and the expected supply of labour.

\section{Figure 1 Schematic overview of the forecasting model}

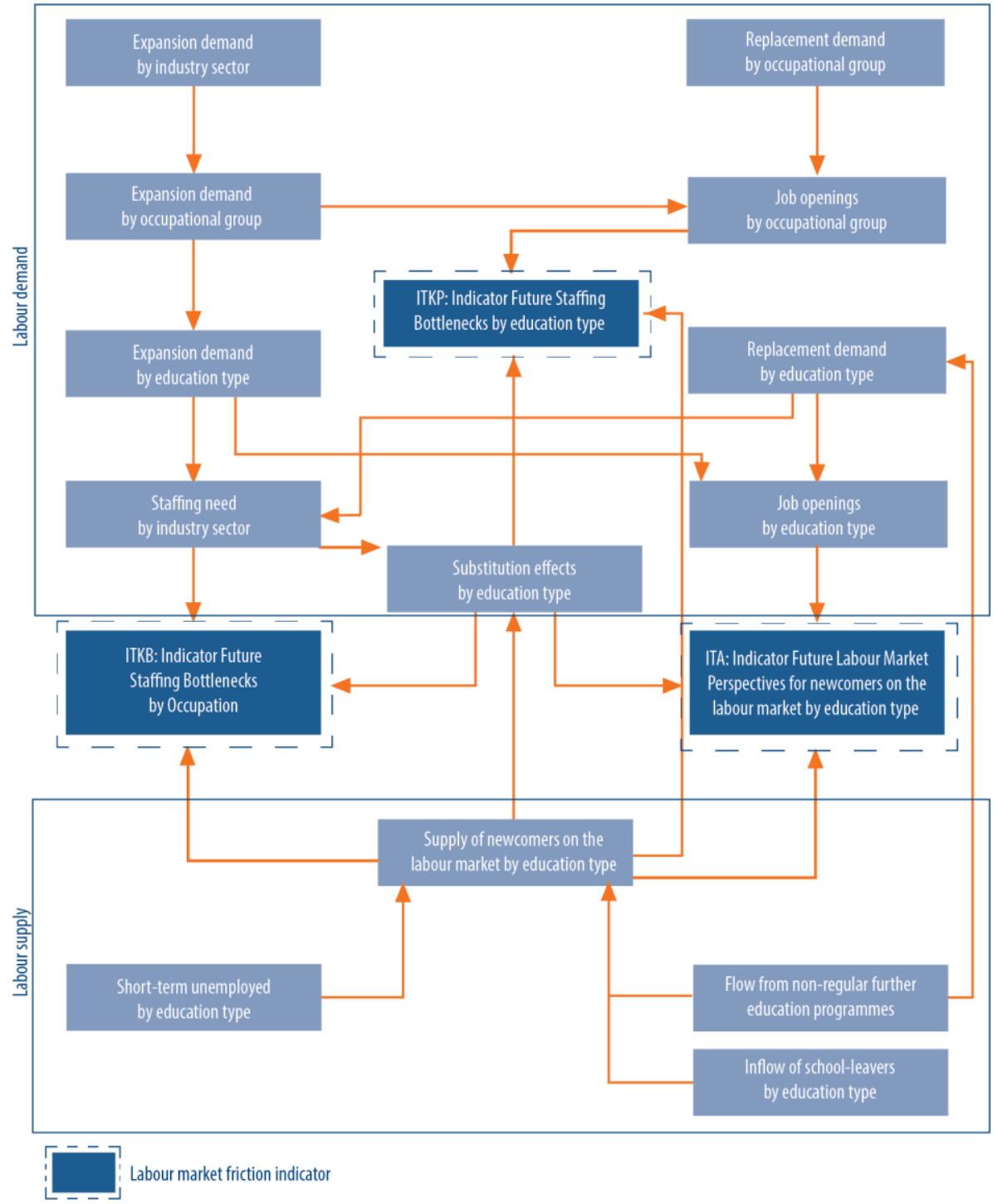

7. The methodology that was used for the forecasts will be published soon. The details of the methodology used can be found in: Bakens, J., Bijlsma, I., Dijksman, S., Fouarge, D., \& de Lombaerde, G. (2020), Methodiek arbeidsmarktprognoses en -indicatoren 2019-2024, Universiteit Maastricht: ROA-TR-2020/3. 


\section{Demand for labour}

Expansion demand is an important flow variable on the demand side of the labour market. It represents the expected employment creation in a certain occupational group or type of education. In case of job destruction expansion demand can be negative. To compute the expansion demand by occupation and education, the model uses macroeconomic data on the expected employment growth at the level of 21 industry sectors. This data is based on estimates of the economic growth, employment, and participation rates from the Netherlands Bureau of Economic Policy Analysis (CPB). More specifically, for the most recent labour market forecasts, estimates from the CPB's Central Economic Plan (CEP) of 2019 are used. ${ }^{8}$ The expected annual economic growth rate used for the years 2019 and 2020 is $1.5 \%$. The average employment growth used until 2024 is $0.9 \%$.

\section{Expansion and substitution demand}

The macroeconomic estimates of the CPB are differentiated for 21 industry sectors. ${ }^{9}$ The forecasts pertain to the number of workers and jobs, as well as to the added value and capital investments by sector. These are used in the ROA models to estimate the expansion demand by occupation. Furthermore, these projections are in line with the sector forecasts of the Employee Insurance Agency (UWV) so as to ensure a high degree of consistency and comparability between ROA and UWV forecast data. ${ }^{10}$

Starting from the projected expansion demand in the various industry sectors, the expected shifts in the occupational structure within these sectors are predicted first. ${ }^{11}$ The possibility that certain occupational groups could grow faster than others, for example, as a result of technological change or an increasing internationalisation of certain sectors, is accounted for. Apart from the shifts in the size and structure of employment in the last 20 years, a number of additional explanatory variables (such as value-added and investment) are included in the occupation model for the expansion demand in order to forecast the expansion demand by occupation. ${ }^{12}$

Next, the expansion demand by education type is predicted from the estimated demand by occupational groups. The estimation explicitly takes into account shifts in the educational composition within occupational groups. ${ }^{13}$ The expansion demand by education type refers to the number of workers with a specific educational background

8. $\quad$ CPB (2019), Central Economic Plan 2019, Den Haag.

9. The sectoral delineation we use is based on the classification of the European Union (Nomenclature statistique des activités économiques dans la Communauté Européenne, NACE). The differentiation by industry sector was computed by research company Panteia.

10. UWV (2018), UWV Arbeidsmarktprognose 2018-2019: https://www.uwv.nl/overuwv/kenniscijfers-en-onderzoek/arbeidsmarktinformatie/uwv-arbeidsmarktprognose-2018-2019.aspx

11. This is done by using allocation matrices of occupation by industry sector for the period 1996-2018.

12. F. Cörvers \& A. Dupuy (2010), Estimating employment dynamics across occupations and sectors of industry, Journal of Macroeconomics, 32: 17-27.

13. A. Dupuy (2006), Measuring Skill-upgrading in the Dutch Labor Market, ROA-W-2006/3E, Maastricht: ROA. 
that employers would like to hire for their production process. A key feature of the model is that ex-ante substitution possibilities across types of workers in terms of their educational background are explicitly modelled. ${ }^{14}$ If the demand for a specific type of educational degree within occupational groups exceeds the supply, this excess demand will in the model affect the demand for related fields. However, the actual growth in the number of workers per education type will usually deviate from the predicted growth due to the interaction between the demand and the supply side of the labour market and, subsequently, the resulting substitution processes: if the current supply of specific education degrees falls short of employers' demand, employers will seek to fill their vacancies by hiring persons with a related degree. Ex-post adaptation mechanisms are not accounted for in the model (see Section 2.2). The employment projections by occupation and education make intensive use of the LFS time series data of Statistic Netherlands (years 1996-2018).

\section{Replacement demand and job openings}

The labour market is also characterized by replacement demand resulting from, for example, (early) retirement, outflow due to disability, temporary withdrawal from the labour market and occupation mobility. In order to determine the replacement requirement, the labour force outflow is calculated using expected participation rates by gender across different age cohorts. These are based on the most recent CPBforecasts of the gross participation rate by age and gender. ${ }^{15}$ The forecasting model also incorporates skills-upgrading into the replacement demand. ${ }^{16}$ This upgrading process is estimated from the data. However, when the outflow of a worker in a certain occupation or with a certain educational background does not actually lead to demand for another worker because employment for that occupation of education background is shrinking, no replacement demand occurs. Thus, only part of the labour market outflow actually creates replacement demand.

The replacement demand is computed separately for occupational groups and education types. These are not necessarily equal. The mobility between occupational groups influences the replacement demand by occupational group, but has no effect on the replacement demand per education type because the mobility between occupational groups has no direct consequences for the educational structure of employment, although they can overlap. Conversely, completing further education leads to inflow into another (usually higher) education type, and outflow out of the old one. Replacement demand will then be generated for the old education type, though it will not affect the occupational structure.

Estimates of the outflow patterns by occupation and education are based on the LFS, of which only data for the most recent 10 years are used. In case of an employment increase, the expansion and replacement demand determine the number of job

14. F. Cörvers \& H. Heijke (2004), Forecasting the labour market by occupation and education: Some key issues, ROA-W-2004/4, Maastricht: ROA.

15. The participation rates are proviced by the CPB.

16. For a justification, see chapter 4 in ROA (2015), De arbeidsmarkt naar opleiding en beroep tot 2020, Maastricht: ROA-R-2015/6. 
openings for new entrants to the labour market. In case of a decline in employment, new job openings only consist of replacement demand.

\section{Supply of labour}

The mid-term equilibrium in the labour market is determined by the total demand for labour, and the supply of labour. The labour supply consists of the future labour force inflow of school-leavers and of workers who switch between education types because they complete additional or further education programmes during the forecasting period. The labour supply also includes the short-term and frictional unemployed at the start of the forecasting period. Based on available evidence, the assumption is made that the long-term unemployed (defined as those who have been looking for a job for longer than one year) are no longer serious competitors for school-leavers. ${ }^{17}$

The inflow projections for school-leavers are based on the 2019 baseline forecasts of the Ministry of Education, Culture and Science (OCW) ${ }^{18}$ These are forecasts for the expected inflow of workers from the initial education system into the labour market by broad fields of study. These are refined and supplemented by ROA with projections of the inflow into the post-initial education system on the basis of administrative data (Education Matrix), the LFS of Statistic Netherlands, and ROA's School-leavers Information System (SIS).

\subsection{Labour market friction indicators}

\section{Friction indicator for new inflow into the labour market}

The expected labour supply is confronted with the expected labour demand for each type of education to quantify the future labour market perspectives up to 2024 by occupation and type of educational degree. The resulting Indicator Future Labour Market Perspectives (ITA) is the ratio of the labour supply and labour demand, and it denotes the expected discrepancy between supply and demand for each type of education for the next six years. If the labour supply is smaller than or equal to the labour demand, the ITA is smaller than or equal to 1.00 and the labour market prospect is classified as 'good'. If the value of the ITA is smaller than or equal to 0.85 , the labour market perspective is classified as 'very good'. ${ }^{19}$ When the ITA has a value between 1.00 and 1.05 - and the excess supply is not much larger than what can arguably be regarded as friction - the labour market prospect is 'fair'. Larger values of the ITA

17. The CPB concludes that the unemployment duration is negatively correlated with the relevance of the group for determining the labour market equilibrium (M. de Graaf-Zijl, A. van der Horst \& D. van Vuuren, 2015, Langdurige werkloosheid. Afwachten en hervormen. CPB Policy Brief 2015/11).

18. https://www.rijksoverheid.nl/documenten/rapporten/2019/09/17/referentieraming-ocw-2019

19. The boundaries of the ITA are based on a statistical analysis of the spread of the labour market condition of the different types of education. See M. Wieling, A. de Grip en E. Willems (1990), Een systematische kwalitatieve typering van arbeidsmarktinformatie, ROA-W1990/8, Maastricht: ROA. For an analysis of the significance of the ITA, see also A. Dupuy (2009), An evaluation of the forecast of the indicator of the labour market gap, ROA-TR2009/3, Maastricht: ROA. 
correspond with a 'poor' labour market prospect, and a value greater than 1.15 is regarded as 'bad'.20

It is critical to correctly interpret this friction indicator. Oversupply of labour with a specific educational background does not necessarily mean that graduates will become unemployed, and an undersupply does not automatically imply there will be unfilled job vacancies. This is because such conditions could prompt employers to modify their job requirements or hiring strategy so that they might ultimately hire people with a different educational background than the ones they initially seek to hire. Schoolleavers for which supply exceeds demand will see their labour market position deteriorate, as they will more often be forced to work below their level of education or outside their field of study, and will more frequently have to settle for lower wages and/or part-time positions when they would rather work full-time. ${ }^{21}$ Conversely, a situation of undersupply will likely improve labour market perspectives of the new labour force inflow since they will experience less pressure to accept lower wages or jobs below their level of education. On the one hand, graduates from educational programmes that are displaced by those with an excess-supply will face a smaller number of job openings as a result of substitution. On the other hand, additional job openings will likely be created for graduates from educational programmes that are closely related to those that are in undersupply. In case of frictions, these substitution effects are therefore especially important for the labour market prospects of graduates from these educational programmes. How the market will actually adjust to disbalances between supply and demand is likely to differ across submarkets and impossible to quantify beforehand.

\section{Friction indicator for employers}

The confrontation of supply and demand for each type of education also gives an indication of potential future bottlenecks in staffing. In case of employment growth, the required number of additional workers needed with a specific educational background is equal to the sum of the expansion and replacement demand. When the employment for the education type is shrinking, however, the required number of additional workers is computed in a different way than the number of job openings for new entrants on the labour market. This is because, from the viewpoint of employers, there is a possibility to cut the outflow of existing personnel (negative expansion demand per education type) when bottlenecks appear. Employers will mainly use this option when they are confronted with a tight labour market for workers with a certain type of education. An

20. ROA frequently evaluates the quality of its forecasts. With regards to replacement demand, see for example R. Montizaan (2009), Evaluatie vervangingsvraagprognoses naar opleiding en beroep, ROA-TR-2009/1, Maastricht: ROA. This evaluation shows that the previous forecasts were able to correctly predict the ITA-characterization (out of five options) for over $40 \%$ of the education types, while for approximately $80 \%$ of the education types a correct or neighbouring characterization was given. See A. Dupuy (2009), An evaluation of the forecast of the indicator of the labour market gap, ROA-TR-2009/3, Maastricht: ROA; D. Bertrand-Cloodt (2010), Evaluatie uitbreidingsvraag en indicator toekomstig arbeidsmarktperspectief (ITA) tot 2008, ROA-TR-2010/6, Maastricht: ROA.

21. M. Wieling \& L. Borghans (2001), Discrepancies between supply and demand and adjustment processes in the labour market, Labour, 15: 33-56. 
indication of the expected staffing difficulties for employers is given by the Indicator Future Staffing Bottlenecks (ITKP).

\section{Labour market friction by occupation}

The central focus of this report is the relationship between educational attainment and work in the labour market, i.e., the matching of employers' demand for workers with specific educational backgrounds and the supply of workers with these backgrounds. In addition to friction indicators by type of education, insight is provided into the implications of the supply and demand ratios for the potential staffing bottlenecks by occupational group. The Indicator Future Staffing Bottlenecks by Occupation (ITKB) reflects this expected labour market friction by occupation. More specifically, it represents the chance that the desired educational composition of the personnel structure within a certain occupational group in the labour market can actually be realised given the predicted supply and demand dynamics of the underlying education types. The ITKB takes into account the expected supply of student labour, which is relevant in the Dutch economy as many youngsters hold a small part-time job. ${ }^{22}$ Failure to take this into account would overestimate staffing bottlenecks in occupations that employ a lot of students and have a high degree of staff rotation (such as, for example, shelf stackers).

Information on the staffing bottlenecks by occupational group can be relevant for a variety of stakeholders. Firstly, an understanding of these bottlenecks informs the recruitment and personnel departments of employers. Secondly, it can guide (longterm) unemployed people who are looking for a job or a different type of work environment towards opportunities in the labour market. Closely related to this last use are the (re-)training programmes that usually focus on a certain occupational group. Insight into the staffing bottlenecks by occupation could inform the way in which these training programmes are set up.

The total expected demand during the forecasting period for a certain occupation is related to the way in which employers would like to structure their labour demand for a specific occupation by educational background, as well as to the supply and demand ratios for the types of education that are relevant to that occupation. This gives an indication of the difficulties employers will face during their hiring process. When a certain occupation requires skills and expertise primarily possessed by people with educational backgrounds that are expected to suffer from substantial shortages, employers will face challenges in finding personnel that meets their job requirements. These bottlenecks will be especially pronounced when the required professional expertise is very specific and lacks available alternatives. Conversely, when the required competencies are more general, employers can usually hire people with a different educational background as there is more room for substitution.

22. CBS (2017). Ruim vier op de tien scholieren werken. https://www.cbs.nl/nlnl/nieuws/2017/13/ruim-vier-op-de-tien-scholieren-werken; I. Bijlsma, S. Dijksman, D. Fouarge, A. Künn-Nelen \& D. Poulissen (2015), Veranderingen in de omvang en samenstelling van de beroepsbevolking als gevolg van de overstap op de ILO-definitie van de beroepsbevolking, Maastricht: ROA-TR-2015/6. 


\subsection{New educational classification (ONR2019)}

As mentioned, the LFS is an important data source for the ROA-forecasts because it is the only extensive dataset in the Netherlands that measures both the occupation and educational background of workers, and has a long time dimension. Statistics Netherlands redesigned the coding of the field of education from ISCEDF1997 to ISCEDF2013. As a result, and in close cooperation with Statistics Netherlands and UWV, ROA has derived an educational classification that distinguishes between educational level and field that is derived from ISCEDF2013 and that is relevant to the educational structure of the Netherlands. In total, the classification distinguishes between 137 educational types (level and field). It is important to note that implementation of the new educational classification hinders comparisons between the educational forecasts from previous years. 


\section{Forecasts by education and occupation}

\subsection{Future labour market prospects by education}

Although economic growth is stabilising in the next couple of years, the labour market prospects for recent graduates for the period 2019-2024 are generally good. ${ }^{23}$ Table 1, which displays the Indicator Future Labour Market Perspectives (ITA), shows that over this period the labour market perspectives for over $40 \%$ of graduates are good or very good. However, differences between educational levels and fields can be substantial: the higher the education level, the better the prospects. Graduates with bachelor and master degrees generally face more favourable prospects. Engineering and ICT graduates, as well as graduates in education and health at the bachelor or master level have the best prospects. Especially the demand for graduates in engineering and ICT, health and education at the bachelor and master level is high, as scarcity of technically schooled staff and shortages in healthcare and education are expected to persist for the next few years. Economics and law score weakly at the bachelor level, due to the large inflow of graduates while demand lags behind. However, for master graduates in economics and law, the prospects until 2024 are fair.

Labour market prospects for secondary vocational education (mbo) graduates are generally less favourable compared to those of bachelor and master graduates. Table 1 shows that only graduates with an mbo 2 level degree in welfare and services have good prospects. The forecasts show that the expected inflow of graduates into the labour market is lower than the expected amount of job openings. A similar pattern is shown at the mbo 3 level: economy and administration, as well as commerce, business and transport services have weak or bad ITA scores. Automation and skills-upgrading play an important role in the lowered demand of graduates within this educational field. At the mbo 4 level, the only two fields with good scores are food, nature and environment, and engineering, construction and processing. A high replacement demand and aging of the sector's workforce causes the good prospects for food, nature and environment. Engineering, construction and processing has a high replacement demand compared to the expected graduate inflow. Note that the 'fair' forecasts for health and welfare programmes at mbo 3 and 4 level hide an underlying diversity with good prospects for health-related programmes but worse forecasts for welfare-related ones.

23. This is, as indicated in Chapter 1 , disregarding the 2020 covid-19 crisis. 
Table 1

Future labour market prospects by education (ITA) for school-leavers, and the share of supply with bad/weak and (very) good labour market prospects, 2019-2024

\begin{tabular}{|c|c|c|c|c|}
\hline & \multirow[t]{2}{*}{ ITA } & \multirow{2}{*}{$\begin{array}{r}\text { Qualification } \\
\text { labour } \\
\text { market } \\
\text { prospects } \\
\end{array}$} & \multicolumn{2}{|c|}{$\begin{array}{l}\text { Labour market prospects } \\
\text { by education type }\end{array}$} \\
\hline & & & $\begin{array}{r}\text { Bad / } \\
\text { Weak } \\
\text { prospects } \\
(\%) \\
\end{array}$ & $\begin{array}{r}\text { (Very) } \\
\text { Good } \\
\text { prospects } \\
(\%) \\
\end{array}$ \\
\hline mbo 2 - economy and society & 1,06 & weak & 100 & 0 \\
\hline mbo 2 - agriculture and nature & 1,02 & fair & 0 & 0 \\
\hline mbo 2 - engineering and ICT & 1,03 & fair & 0 & 0 \\
\hline mbo 2 - welfare and services & 0,99 & good & 0 & 100 \\
\hline mbo 3 - economy and administration & 1,08 & weak & 100 & 0 \\
\hline mbo 3 - commerce, business and transport services & 1,18 & bad & 100 & 0 \\
\hline mbo 3 - food, nature and environment & 1,02 & fair & 50 & 22 \\
\hline mbo 3 - ICT, media and design & 1,06 & weak & 59 & 41 \\
\hline mbo 3 - engineering, construction and processing & 1,01 & fair & 0 & 38 \\
\hline mbo 3 - services & 1,05 & fair & 45 & 0 \\
\hline mbo 3 - health and welfare & 1,02 & fair & 0 & 2 \\
\hline mbo 4 - economy and administration & 1,10 & weak & 100 & 0 \\
\hline mbo 4 - commerce, business and transport services & 1,08 & weak & 31 & 0 \\
\hline mbo 4 - food, nature and environment & 0,88 & good & 0 & 100 \\
\hline mbo 4 - ICT, media and design & 1,22 & bad & 100 & 0 \\
\hline mbo 4 - engineering, construction and processing & 0,87 & good & 0 & 100 \\
\hline mbo 4 - services & 1,10 & weak & 72 & 8 \\
\hline mbo 4 - health and welfare & 1,04 & fair & 48 & 43 \\
\hline bachelor - services & 1,17 & bad & 100 & 0 \\
\hline bachelor - economics and law & 1,08 & weak & 79 & 0 \\
\hline bachelor - journalism, behavioural and social sciences & 1,17 & bad & 100 & 0 \\
\hline bachelor - arts, language and humanities & 1,05 & fair & 75 & 0 \\
\hline bachelor - agriculture, mathematics and natural sciences & 0,97 & good & 0 & 32 \\
\hline bachelor - engineering and ICT & 0,87 & good & 0 & 100 \\
\hline bachelor - health and welfare & 0,99 & good & 22 & 78 \\
\hline bachelor - education & 0,93 & good & 0 & 100 \\
\hline master - economics and law & 1,05 & fair & 21 & 23 \\
\hline master - journalism, behavioural and social sciences & 1,06 & weak & 57 & 0 \\
\hline master - art, language and humanities & 1,01 & fair & 53 & 47 \\
\hline master - agriculture, mathematics and natural sciences & 1,05 & fair & 57 & 0 \\
\hline master - engineering and ICT & 0,92 & good & 0 & 100 \\
\hline master - health & 0,92 & good & 0 & 100 \\
\hline master - education & 0,96 & good & 0 & 100 \\
\hline Total & 0,98 & good & 100 & 43 \\
\hline
\end{tabular}




\subsection{Future labour market prospects by occupation}

The generally good labour market prospects for graduates determine then how easily employers can find workers with a specific educational background for a specific occupation. In other words, how good supply meets demand. The Indicator Future Staffing Bottlenecks by Occupation (ITKB) gives the probability that the demand for a certain occupational group can be met in terms of educational composition, given the supply and demand ratios for the different education types. ${ }^{24}$ Table 2 shows the ITKB for 12 occupational classes (that groups occupations in a similar field of expertise) for the period 2019-2024. The remaining columns display the share of the demand for which employers are expected to have (almost) no, some, or (very) large bottlenecks.

The future staffing bottlenecks are largest in care and welfare occupations, technical and ICT occupations, and educational occupations (pedagogical occupations). Especially for the first two there seem to be less alternatives for a specific educational background and occupation, which makes it more difficult to find suitable personnel. In the case of education, these bottlenecks are caused by a low inflow of graduates with this educational background. Furthermore, workers with a background in education often end up in other occupations. The large demand for workers with a technical and ICT background can be explained by the increasing digitalisation in all sectors of the economy. The staffing bottlenecks in healthcare and education, which is the topic of heated policy debates, is expected to last the following six years. Improving the labour conditions and the image of these occupations could be a possible way to ensure that young people choose these more often.

24. The forecasts also account for the expected supply of students who are looking for a student (small) job. 
Table 2

Future Staffing Bottlenecks by Occupation (ITKB) for employers, and the share of demand with no / almost no bottlenecks and (very) large bottlenecks (by ITKB-qualification), 2019-2024

\begin{tabular}{|c|c|c|c|c|}
\hline & \multirow[t]{2}{*}{ ITKB } & \multirow{2}{*}{$\begin{array}{l}\text { ITKB- } \\
\text { qualification }\end{array}$} & \multicolumn{2}{|c|}{ Bottlenecks by occupational class* } \\
\hline & & & $\begin{array}{c}\% \text { no } \\
\text { bottlenecks }\end{array}$ & $\begin{array}{c}\% \text { large } \\
\text { bottlenecks }\end{array}$ \\
\hline Pedagogical occupations & 0.842 & large & 35 & 65 \\
\hline Creative and linguistic occupations & 0.874 & some & 25 & 42 \\
\hline Commercial occupations & 0.924 & almost none & 100 & 0 \\
\hline Business and administrative occupations & 0.906 & almost none & 66 & 8 \\
\hline Managers & 0.859 & large & 3 & 54 \\
\hline Public order, security and judicial occupations & 0.859 & large & 22 & 56 \\
\hline Technical occupations & 0.839 & large & 10 & 64 \\
\hline ICT occupations & 0.838 & large & 6 & 82 \\
\hline Agriculture occupations & 0.876 & some & 16 & 56 \\
\hline Care and welfare occupations & 0.835 & very large & 0 & 100 \\
\hline Service occupations & 0.923 & almost none & 96 & 0 \\
\hline Transport and logistics occupations & 0.928 & none & 100 & 0 \\
\hline Total & & & 47 & 39 \\
\hline
\end{tabular}

* The occupational classes contain underlying occupational groups. The percentages show the share of the underlying occupational groups, weighted by number of workers, for which no / almost no bottlenecks and (very) large bottlenecks are expected.

Source: ROA (AIS)

Like the previous forecasts up until 2022, large bottlenecks are expected for staffing of managers. These bottlenecks can partly be explained by the fact that a significant percentage of managers is employed in sectors where bottlenecks are expected, such as education, ICT or healthcare. These managers also have educational backgrounds with favourable ITAs. It is therefore harder to find managers with fitting educational backgrounds for the available job openings in this category of occupations. For commercial occupations, economic and administrative occupations, and transport and logistic occupations, no problems are expected in the staffing of new personnel. The inflow of new workers for these occupations is large enough to meet the demand by employers.

\subsection{General expected labour market developments}

\section{The replacement demand is the principal cause of job openings}

The following six years, over 2 million job openings are expected. The fact that people who leave the labour market for reasons such as unemployment, migration, (early) retirement, childcare, or labour disability, need to be replaced, is the main cause of these job openings. The replacement demand thus remains the most important driver of the number of job openings in the coming years. With 1.6 million people needing to be replaced, the replacement demand is about three quarters of total demand for labour. The rest of the job openings are determined by expected job creation, which consists of about 465.000 additional workers. The occupations for which the largest 
replacement demand (in absolute numbers) is expected are the business and administrative occupations, the transport and logistics occupations, the technical occupations and the commercial occupations. For the ICT occupations the replacement demand is low because the average age in these occupations is rather low. For this reason more than half of the job openings is due to expansion demand.

\section{Additional employment for care and technical occupations}

The largest employment growth is foreseen for the care and welfare occupations and the technical and engineering occupations. This partly explains the overall good labour market prospects for graduates from the educational fields that train for these occupations. The only occupations for which we expect a decline in demand are agricultural occupations. This could be caused by the fact that the intensification of labour in this sector continues to be driven by technological advancements.

\section{More higher educated workers in the Netherlands}

In the period from 2019 to 2024 , there are expected to be about 1.6 million graduates who enter the labour market. Due to demographic developments, the number of graduates is not growing but the composition is changing. For graduates with a vocational education at level 2 or 3 , a decrease of the inflow is forecasted, for vocational education at level 4 , and bachelor and master an increase of the inflow is forecasted. The largest inflow of graduates in absolute numbers is expected from ICT, media and design and care and welfare at the vocational education level, the bachelor personal services and the bachelor and master in social and behavioural sciences and journalism.

\section{Historically low unemployment, but job certainty is low for low-educated youngsters}

The economic growth of the last years is slowing down and unemployment is historically low. This is true for all age categories. For youngsters, who suffered the most from the credit crisis of 2008 , the unemployment rate declined from $13.2 \%$ in 2013 to $6.7 \%$ in 2019. In general, the youth unemployment remains structurally higher compared to other age categories, especially for low-educated youngsters $19 \%$ in 2019). Although low-educated older people are more often unemployed, the difference between the unemployment rate between different educational levels is smaller for the older age categories. The share of youngsters with a flexible employment contract increased remarkably in the last years and is currently about $70 \%$. This flexibility of the labour market increases the job uncertainty among youngsters.

\section{Wages are lagging behind}

The labour market opportunities are clearly better for higher educated workers. While after the credit crisis of 2008 the lower educated experienced a decline in both wage and employment, high educated mainly experienced a decline in wage (see Figure 1). Furthermore, the decline in wage was less severe for the high educated. The decline in unemployment since 2013 and the increasing tightness of the labour market were not unambiguously accompanied by an increase in wages. The wages of the low educated declined in real terms and the wages of high educated increased slightly. 
The lagging increase in wages, specifically for the lower educated, is probably the consequence of lower labour productivity growth.

\section{Figure 1}

Relationship between net labour market participation and mean gross hourly wage* by education level of employees, indexed $(2008=100) 2008-2018$

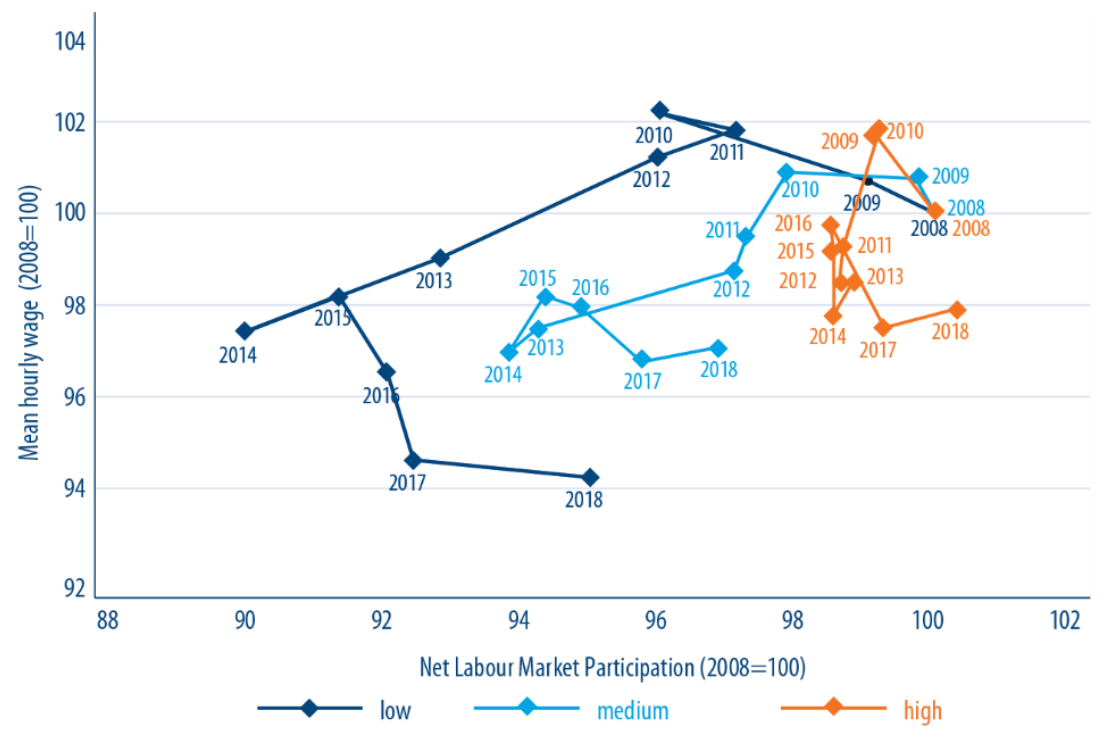

* The index number for gross hourly wage is calculated based on the hourly wage in 2015 constant prices.

Source: ROA, EBB-SSB (ROA edit) 


\section{Relevance of labour market information ${ }^{25}$}

\subsection{Use of labour market information by stakeholders}

The idea behind the labour market forecasts and the publication of these forecasts is that a more transparent labour market leads to better-informed choices. It is hard to define precisely what that means. However, at the micro level this could result in fewer graduates being unemployed or regretting their decision for a particular field of study. At the macro level it could result in an improved match between supply and demand. ${ }^{26}$

The labour market information developed as part of POA is relevant for numerous target groups. One important target group consist of youngsters and job seekers who are in the process of choosing an education or further education programme. The analyses in POA enables them to base their choice on the medium-term labour market prospects of various study programmes and occupations. A number of websites (www.studiekeuze123.nl) and information guides (www.keuzegids.org) help to bring this information to this target group. This informative role is further taken on by various independent organisations in the field of education, such as the Cooperation Organisation for Vocational Education, Training and the Labour Market (SBB) (www.kansopwerk.nl), which use data generated within POA in their dissemination of information. Research shows that youngsters benefit from transparent labour market information (see below).

Labour market forecasts are also relevant for employers, labour market mediators, and policy makers. Employers can, for instance, adapt their recruitment strategy or terms of employment as a result of a predicted imbalance between supply and demand, while labour market mediators and related organisations can use the information to adjust their integration and training programmes (organisations such as employment agency Randstad, and the Employee Insurance Agency (UWV) use the POA-forecasts in their mediation activities). Policy makers can use POA-forecasts to design policies to ensure that expected personnel shortages in, for example, the technical or education sector are reduced. Furthermore, since 2016, the Commissie Doelmatigheid Hoger Onderwijs $(\mathrm{CDHO})$, which is responsible for the accreditation of new study programmes in higher education, uses the POA-forecasts in their efficacy evaluations to avoid that fields that are in excess-supply start up new education programmes.

Finally, the forecasts are meant to inform labour market policy in a broad sense. This can entail, for example, target group policies, measures aimed at increasing labour market participation, and measures specifically targeted at the bottom of the labour market. POA is therefore an important and relevant project that not only serves the public interest, but also informs the entire field of the education and the occupation

25. Based on Bakens, J., Fouarge, D., \& Peeters, T. (2018). Labour market forecasts by education and occupation up to 2022. Maastricht: ROA-TR-2018/3.

26. Fouarge, D. (2017). Veranderingen in werk en vaardigheden. Oratie, Maastricht University. 
spectrum. ${ }^{27}$ The project also enjoys international recognition, and ROA frequently informs foreign delegations about the forecasting model and its applications. ${ }^{28}$

\subsection{Labour market transparency and field-of-study choice}

Many factors play a role in the educational and occupational choices of youngsters. For instance, preferences for specific fields or the expected match between academic aptitudes and the aptitudes required to fulfil a study programme matter. ${ }^{29}$ These expectations themselves are a function of the social context (such as the influence of parents and friends) and earlier experiences. ${ }^{30}$ Furthermore, according to the human capital theory, the choice for a particular education can be regarded in the same way as any other form of investment: a trade-off between the costs (time and money invested) and benefits (job and wage prospects) of an education. ${ }^{31}$

Evidently, the choice for a particular field of study is not always the result of a rational assessment by youngsters of what they believe they can achieve with it later on. Nevertheless, scientific literature typically finds that youngsters do react to information about the labour market prospects of educations, and that this influences their choice of study. ${ }^{32}$ More specifically, the literature suggests that youngsters who receive such information: 1) have higher expectations regarding the benefits of education; 2) have more intention to stay in school; 3) more often follow further, additional education programmes; 4) opt for fields of education with favourable jobs and wage prospects. The literature, however, is rather scant, and the size of the effects of labour market information on the choice of study varies significantly across studies.

In a POA-related study of graduates of Dutch secondary vocational education (mbo) ROA finds that the labour market prospects of an education are clearly not the primary consideration of youngsters in their decision making process for a particular study. Instead, they give most weight to what they enjoy doing and what they are good at. ${ }^{33}$ Nevertheless, the study shows a positive correlation between the extent to which mbo-

27. For an overview of the target groups and the use of POA, see: Fouarge, D. (2015), Project Onderwijs-Arbeidsmarkt: Gebruik van arbeidsmarktinformatie en impact, ROA, Maastricht: ROA-TR-2015/4.

28. As part of an international consortium led by Cambridge Econometrics, ROA collaborates with international partners to create the Cedefop 'skills supply and demand forecast'. In addition, in 2016 ROA organised a workshop about labour market forecasts intended for delegations of former Eastern European countries on behalf of the European Training Foundation. In the same year ROA also instructed the Analysis Division at the Danish Ministry of Higher Education and Science on the methodological process behind the prognoses. In 2017 ROA acted as an expert during the Paris-held international Skills Forecast Workshop (organised by France Stratégie), as well as during the seminar on Skills Forecasting in the South Mediterranean Area (organised by UNESCO).

29. Arcidiacono, P., Hotz, V. J., \& Kang, S. (2012). Modeling college major choices using elicited measures of expectations and counterfactuals. Journal of Econometrics, 166(1), 3-16.

30. Joensen, J. S., \& Nielsen, H. S. (2017). Spillovers in education choice. Journal of Public Economics. Forthcoming.

31. Wiswall, M., \& Zafar, B. (2014). Determinants of college major choice: Identification using an information experiment. Review of Economic Studies, 82(2), 791-824.

32. See for a review: Fouarge, D., A. Künn-Nelen \& A. Mommers (2016), Studiekeuze en arbeidsmarkt: literatuurstudie, Maastricht: ROA-R-2016/3.

33. Fouarge, D., Künn, A., Punt, D. (2017), De rol van arbeidsmarktinformatie in de opleidingskeuze van mbo'ers, Maastricht: ROA-R-2017/9. 
graduates weigh future career prospects in their decision making process and their actual labour market outcomes in terms of employment, wages, job satisfaction, and working at their level of education and in their field of study. Moreover, mbo-graduates who gave (a lot of) consideration to career prospects are less likely to regret their educational choices later on.

That same study also investigated the trade-off between preferences, competencies and labour market prospects. This was done by conducting a choice experiment (vignette study) in which youngsters had to choose between two mbo-programmes. The resulting analyses suggest, first of all, that youngsters do take the expected labour market prospects of study programmes into account during their decision making process. Secondly, the choice experiment showed that negative signals (irrespective of whether they referred to bad employment opportunities or to a mis-match with the individuals' interests) have more impact on not choosing for a specific field of study than positive signals have on choosing for a field. Finally, the results suggest that prospective students would be willing to opt for a field of study that is not the first match with their preferences if the labour market prospects for that field are comparatively more favourable than those of the field that best matches with their preferences.

In an ongoing field experiment, we measure the occupational preferences of students in vocational education. ${ }^{34}$ We then test for the causal effect of providing information about employment and wage prospects for occupations that these students like on their preference ranking. Our results indicate that 1) students overestimate the job opportunities and wages of occupations that they like, 2) giving them information about actual job opportunities and pay helps to correct wrong expectations, and 3) when students have received information about the actual job opportunities and pay of the occupations they like, they more often rank occupations with the best job opportunities and pay at the top of their preferred occupations.

34. https://www.socialscienceregistry.org/trials/3220 